\begin{tabular}{|c|c|c|}
\hline & Int.J.Curr.Microbiol.App.Sci (2021) 10(01): 155-164 & \\
\hline EXCELLENT & $\begin{array}{l}\text { International Journal of Current Microbiology and Applied Sciences } \\
\text { ISSN: 2319-7706 Volume } 10 \text { Number } 01 \text { (2021) } \\
\text { Journal homepage: http://www.ijcmas.com }\end{array}$ & 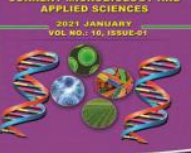 \\
\hline $\begin{array}{l}\text { EXCELLENT } \\
\text { PUBLISHERS }\end{array}$ & & \\
\hline
\end{tabular}

\title{
Effect of Non-genetic Factors on Monthly Milk Yield HF $\times$ GIR Halfbreds
}

\author{
Ghoshita Suryakant Hingonekar*, Dilip Kundalik Deokar, Swapnali Uttamrao Rokade \\ and Harshavardhan Shahaji Sonawane
}

Department of Animal Husbandry and Dairy Science, College of Agriculture, Dhule, Mahatma PhuleKrishiVidyapeeth, Rahuri, India

*Corresponding author

\section{A B S T R A C T}

\begin{tabular}{l}
\hline Ke y w or d s \\
HF $\times$ Gir halfbreds, \\
MMY1, MMY2, \\
MMY3, MMY5, \\
MMY6, MMY7, \\
MMY8, MMY9, \\
MMY10 \\
\hline Article Info \\
\hline $\begin{array}{l}\text { Accepted: } \\
\text { 04 December } 2020 \\
\text { Available Online: } \\
\text { 10 January } 2021\end{array}$ \\
\hline
\end{tabular}

\section{Introduction}

The THI was extensively used in hot region all over the world to evaluate the effect of heat stress on dairy cows. It is currently used to estimate cooling necessity of dairy cattle in order to improve the efficiency of management strategies to alleviate the negative effect of heat stress. Increased pressure for intensified milk production and simultaneous rise in environmental temperature due to global warming has increased the thermal load on dairy animals. Elevated environmental temperature
The data on production performance of $\mathrm{HF} \times$ Girhalfbreds maintained at Research cum Development Project on Cattle (RCDP), Mahatma Phule Krishi Vidyapeeth, Rahuri district, Ahmednagar, (M.H) were utilized for present study. The least squares means of total milk yield (kg), lactation length (days), dry period (days) and peak milk yield $(\mathrm{kg})$ were estimated by considering the effects of period of calving, season of calving and lactation order as non-genetic factors. Then data were corrected for significant non genetic factor effect and effect of THI was estimated. Then data were corrected for significant non genetic factor effect and effect of THI was estimated. The effect of factor period of calving was significant from MMY1 to MMY8 $(\mathrm{P}<0.01)$ while it was non significant in MMY 9 and MMY10; the effect of factor season of calving was not significant on MMY1 to MMY10; the effect of order of lactation was significant on MMY1 to MMY4 $(\mathrm{P}<0.01)$ while it was non significant on traits from MMY 5 to MMY 10. 
method to assess heat stress on animals. Several research workers have reported that there exists a threshold THI value, above which the negative effects of heat stress is observed on animals. Mitigation strategies to combat heat stress includes selection of heat tolerant animals and their breeding, inclusion of heat tolerance as a trait while constructing selection index, providing balanced nutrition to the animals and implementation of good ventilation along with suitable cooling system in the farm(Behera et al., 2020).

\section{Materials and Methods}

The data of $\mathrm{HF} \times$ Girhalfbreds maintained at Research Cum-Development Project on Cattle, M.P.K.V., Rahuri for a period from 2009 to 2019 (10 years) were collected for present investigation for following Traits:

a)Productive traits:1) Total lactation milk yield (kg),2) Lactation length (days),3) Dry period (days),4) Peak milk yield (kg).

To examine the Production traits, the research data was classified into 3 periods of calving viz. $\mathrm{P}_{1}$ (2009-2011), $\mathrm{P}_{2}$ (2012-2014), $\mathrm{P}_{3}$ (2015 above); 3 seasons of calving, viz. $\mathrm{S}_{1}$ (Rainy) June- September, $\mathrm{S}_{2}$ (Winter) OctoberJanuary and $\mathrm{S}_{3}$ (Summer) February-May; 5 order of lactation viz. $\mathrm{L}_{1}$ first lactation, $\mathrm{L}_{2}$ second lactation, $\mathrm{L}_{3}$ third lactation, $\mathrm{L}_{4}$ fourth lactation, L $_{5}$ fifth lactation; The effects of nongenetic factors like period of calving, season of calving and parity were estimated by using least-square analysis as suggested by Harvey (1990). The model was used with the assumption that different components being fitted into the model were as linear, independent and additive. The model used was as follows:

\section{Model I}

$Y_{i j k l}=\mu+A_{i}+B_{j}+C_{k}+e_{i j k l}$ where $Y_{i j k l}$, observation of $1^{\text {th }}$ animal, $k^{\text {th }}$ parity, $\mathrm{j}^{\text {th }}$ season of calving, $\mathrm{i}^{\text {th }}$ period of calving; $\mu$ overall mean, $A_{i}$ fixed effect of $i^{\text {th }}$ period of calving ( 1 to 3 ), $B_{j}$ fixed effect of $j^{\text {th }}$ season of calving (1 to 3 ), $\mathrm{C}_{\mathrm{k}}$ fixed effect of $\mathrm{k}^{\text {th }}$ parity (1 to 5); $\mathrm{e}_{\mathrm{ijkl}}$ random error $\sim$ NID $(0$, $\left.\sigma^{2} \mathrm{e}\right)$.

\section{Duncan's Multiple Range Test (DMRT)}

Duncan's Multiple Range Test as modified by Kramer (1957) was used to make pair wise comparison among the least square means with the use of inverse elements and root mean squares for error.

If the values:-

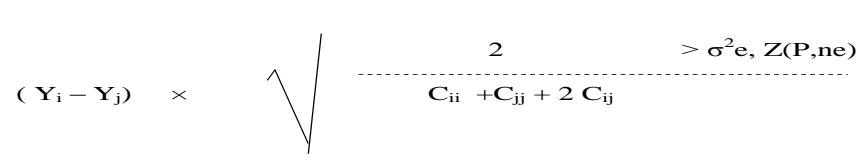

Where,

$Y_{i}-Y_{j}$ : Difference between two least squares means

$\mathrm{C}_{\mathrm{ii}}$ : Corresponding $\mathrm{i}^{\text {th }}$ diagonal elements of $\mathrm{C}$ matrix

$\mathrm{C}_{\mathrm{jj}}$ : Corresponding $\mathrm{j}^{\text {th }}$ diagonal elements of $\mathrm{C}$ matrix

$\mathrm{Z}$ ( $\mathrm{P}$, ne): Standardized range value in Duncan's table at the chosen level of probability for the error degrees of freedom

P: Number of means involved in the comparison

$\sigma^{2} \mathrm{e}:$ Rootmean squares for error

Results and Discussion

The overall least squares means in HF $\times$ Girhalfbreds from $362.46 \pm 9.68$, 
$387.64 \pm 10.06,338.98 \pm 15.68,285.73 \pm 8.21,251$ $.65 \pm 8.11,219.39 \pm 7.80,191.12 \pm 7.35$, $172.04 \pm 6.53,144.93 \pm 8.14,130.71 \pm 8.87$, respectively (Table 1 and 2 ).

\section{First monthly milk yield (MMY1)}

The overall least squares mean of Monthly milk yield of first month in $\mathrm{HF} \times$ Girhalfbreds was $387.64 \pm 10.06 \mathrm{~kg}$. The influence of period of calving on monthly milk yield of first month in $\mathrm{HF} \times$ Gir crossbreds was significant $(\mathrm{P}<0.01)$. Similar results were obtained in HF×Girhalfbreds (Deokar et al., 2017), Phule Triveni cows (Kamble, 2014), Kale et al., (2001a) in Triple cross bred, Raut et al., (2017) in HF×Girhalfbreds. In HF $\times$ Girhalfbreds, monthly milk yield of first month $(\mathrm{kg})$ of cows calved during various periods of calving was significantly $(\mathrm{P}<0.01)$ differed from each other. The results revealed that the monthly milk yield of first month linearly decreased in cows calved during succeeding periods over preceding i.e. P1 to $\mathrm{P} 3$ in $\mathrm{HF} \times$ Gir cows.

The variation due to season of calving in first monthly milk yield was non-significant in HF $\times$ Girhalfbreds. This result was in accordance with Deokar et al., (2017) in HF $\times$ Girhalfbreds, Kamble (2014) in Phule Triveni cows and Pandey et al., (2018) and Pandey M. and Raja K.N. (2019) in Sahiwal cattle, Raut et al., (2017) in HF $\times$ Girhalfbreds. However contradictory results were obtained by Kale et al., (2001a) in Triple cross bred. In presents study, the highest MMY1 was observed in cows calved during season summer $(409.47 \pm 16.03 \mathrm{~kg})$ followed by rainy $(380.17 \pm 17.97 \mathrm{~kg})$ and lowest in winter $(373.29 \pm 15.61 \mathrm{~kg})$.

The difference due to order of lactation in first monthly milk yield $(\mathrm{kg})$ was significant $(\mathrm{P}<0.01)$ in $\mathrm{HF} \times$ Girhalfbreds. Similar results were obtained by Kale et al., (2001a) in
Triple cross bred. In HF $\times$ Girhalfbreds, the highest MMY1 was observed in cows during L4 (421.87 \pm 19.38$)$ followed by L5 (418.49 \pm 21.57), L3 (404.74 \pm 20.09), L2 (391.42 \pm 21.98), and lowest in $\operatorname{L1}(301.70 \pm 22.91)$ lactation. In HF $\times$ Gir cows in the present study no specific trend in various lactations was noticed for MMY1.The difference in MMY1 among total cows calved during L4 and L5, L2 and L3 and L4and L1 and L2 and L1 were at par to each other.

\section{Second monthly milk yield (MMY2)}

The overall least squares mean of second monthly milk yield in $\mathrm{HF} \times$ Girhalfbreds was $362.46 \pm 9.68 \mathrm{~kg}$.

The influence of period of calving on second monthly milk yield was significant $(\mathrm{P}<0.01)$. Similar results were reported in $\mathrm{HF} \times$ Girhalfbreds (Deokar et al., 2017), Phule Triveni cows (Kamble 2014), Kale et al., (2001a) in Triple crossbred, Raut et al., (2017) in HF $\times$ Girhalfbreds. In $\mathrm{HF} \times$ Girhalfbreds, monthly milk yield of second month $(\mathrm{kg})$ of cows calved during P1(419.52 \pm 13.77 ) was significantly higher than those in $\mathrm{P} 2(347.99 \pm 14.30)$ and $\mathrm{P} 3(319.86 \pm 21.47)$ which were at par to each other. The difference in second monthly milk yield among total cows calves during P1 was significantly higher than P2 and P3. The difference in MMY2 among total cows calved during P3 and P2 were at par to each other. The results revealed that the monthly milk yield of second month linearly decreased in cows calved during succeeding periods over preceding i.e. $\mathrm{P} 1$ to $\mathrm{P} 3$ in $\mathrm{HF} \times$ Gir cows.

The variation due to season of calving in second month milk yield was non-significant in HF $\times$ Girhalfbreds. This result was in accordance with Varshney and Tomar (1982) in Hariana and different crossbred cattle, Deokar et al., (2017) in HF $\times$ Girhalfbreds, 
Kamble (2014) in Phule Triveni cows, Pandey M. et al., (2018) and Pandey M. and Raja K.N. (2019) in Sahiwal cattle, Raut et al.(2017) in $\mathrm{HF} \times$ Girhalfbreds. However contradictory results were obtained by Kale et al., (2001a) in Triple cross bred. In presents study, the highest MMY2 was observed in cows calved during season winter (371.33 \pm $15.02 \mathrm{~kg})$ followed by summer $(369.76 \pm$ $15.43 \mathrm{~kg})$ and lowest in rainy $(346.29 \pm$ $17.29 \mathrm{~kg}$ ).

The difference due to order of lactation in second month milk yield $(\mathrm{kg})$ was significant $(\mathrm{P}<0.01)$ in $\mathrm{HF} \times$ Girhalfbreds. Similar results were obtained by Kale et al., (2001a) in Triple cross bred. In HF $\times$ Girhalfbreds, the highest MMY2 was observed in cows during L5 $(404.61 \pm 20.76) \mathrm{kg}$ followed by L4 $(380.97 \pm 18.65) \mathrm{kg}$, L3 $(374.20 \pm 19.33) \mathrm{kg}$, L2 $(361.13 \pm 21.15) \mathrm{kg}$, and lowest in L1 $(293.39 \pm 22.05) \mathrm{kg}$ lactation. The difference in MMY2 among total cows calved during L4 and L5, L2 and L3 and L4 and L2 and L1 between L5 and L1 were at par to each other. In $\mathrm{HF} \times$ Gir cows in the present study increasing trend of lactation length was noticed for MMY2 from L1 to L5.

\section{Third monthly milk yield (MMY3)}

The overall least squares mean of Monthly milk yield of third month in $\mathrm{HF} \times$ Girhalfbreds was $338.98 \pm 15.68 \mathrm{~kg}$.

The influence of period of calving on monthly milk yield of third month in $\mathrm{HF} \times$ Gir crossbreds was significant $(\mathrm{P}<0.01)$. Similar results were reported in $\mathrm{HF} \times$ Girhalfbreds (Deokar et al., 2017) and Phule Triveni cows (Kamble 2014), Kale et al., (2001a) in Triple cross bred, Raut et al., (2017) in HF×Girhalfbreds.

In $\mathrm{HF} \times$ Girhalfbreds, monthly milk yield of third month $(\mathrm{kg})$ of cows calved during
$\mathrm{P} 1(423.07 \pm 22.30) \mathrm{P} 2(314.66 \pm 23.16)$ and P3(279.20 \pm 34.77$)$ was significantly differed from each other. The results revealed that the monthly milk yield of third month linearly decreased in cows calved during succeeding periods over preceding i.e. $\mathrm{P} 1$ to $\mathrm{P} 3$ in $\mathrm{HF} \times$ Gircows.

The variation due to season of calving in third monthly milk yield was non-significant in HF $\times$ Girhalfbreds. This result was in accordance with Deokar et al., (2017) in HF $\times$ Girhalfbreds, Kamble (2014) in Phule Triveni cows, Pandey et al., (2018) and Pandey M. and Raja K.N. (2019) in Sahiwal cattle, Raut et al., (2017) in HF $\times$ Girhalfbreds. However contradictory results were obtained by Kale et al., (2001a) in Triple cross bred. In presents study, the highest MMY3 was observed in cows calved during season winter (341.01 \pm $24.33 \mathrm{~kg}$ ) followed by summer (340.46 \pm $24.99 \mathrm{~kg})$ and lowest in rainy (335.46 \pm 28.00 $\mathrm{kg})$.

The difference due to order of lactation in third monthly milk yield $(\mathrm{kg})$ was significant $(\mathrm{P}<0.5)$ in $\mathrm{HF} \times$ Girhalfbreds. Similar results were obtained by Kale et al., (2001a) in Triple cross bred (329.46 \pm 4.56$)$. In HF $\times$ Girhalfbreds, the highest MMY3 was observed in cows during L5 (423.18 \pm 33.62$)$ followed by L4 (356.04 \pm 30.20), L3 (339.57 \pm 31.31), L2(323.92 \pm 34.26), and lowest inL1(252.17 \pm 35.71$)$ lactation. In $\mathrm{HF} \times$ Gir cows in the present study increasing trend of lactation length was noticed for MMY3 from L1 to L5. The difference in MMY3 among total cows calved during L4 and L1, L5 and L2 between L5 and L1 were at par to each other.

\section{Fourth monthly milk yield (MMY4)}

The overall least squares mean of Monthly milk yield of fourth month in $\mathrm{HF} \times$ Girhalfbreds was $285.73 \pm 8.21 \mathrm{~kg}$. 
Table.1 Least square means of MMY 1 TO MMY 6 in HF×Girhalfbreds

\begin{tabular}{|c|c|c|c|c|c|c|c|c|c|c|}
\hline Effect & $\mathbf{N}$ & MMY1 & $\mathbf{N}$ & MMY2 & $\mathbf{N}$ & MMY3 & $\mathbf{N}$ & MMY4 & $\mathbf{N}$ & MMY5 \\
\hline$\mu$ & 169 & $387.64 \pm 10.06$ & 169 & $362.46 \pm 9.68$ & 169 & $338.98 \pm 15.68$ & 169 & $285.73 \pm 8.21$ & 169 & $251.65 \pm 8.11$ \\
\hline \multicolumn{11}{|c|}{ Period of Calving } \\
\hline $\mathbf{P}_{1}$ & 72 & $434.21^{\mathrm{a}} \pm 14.31$ & 72 & $419.52^{\mathrm{a}} \pm 13.77$ & 72 & $423.07^{\mathrm{a}} \pm 22.30$ & 72 & $342.98^{\mathrm{a}} \pm 11.68$ & 72 & $302.76^{\mathrm{a}} \pm 11.54$ \\
\hline $\mathbf{P}_{2}$ & 67 & $388.66^{\mathrm{b}} \pm 14.86$ & 67 & $347.99^{\mathrm{b}} \pm 14.30$ & 67 & $314.66^{\mathrm{b}} \pm 23.16$ & 67 & $272.30^{\mathrm{b}} \pm 12.13$ & 67 & $244.45^{\mathrm{b}} \pm 11.98$ \\
\hline $\mathbf{P}_{3}$ & 30 & $340.06^{\mathrm{c}} \pm 22.31$ & 30 & $319.86^{\mathrm{bc}} \pm 21.47$ & 30 & $279.20^{c} \pm 34.77$ & 30 & $241.92^{c} \pm 18.21$ & 30 & $207.75^{c} \pm 17.99$ \\
\hline \multicolumn{11}{|c|}{ Season of Calving } \\
\hline $\mathbf{S}_{1}$ & 47 & $380.17 \pm 17.97$ & 47 & $346.29 \pm 17.29$ & 47 & $335.46 \pm 28.00$ & 47 & $262.76^{c} \pm 14.66$ & 47 & $228.75 \pm 14.49$ \\
\hline $\mathbf{S}_{2}$ & 60 & $373.29 \pm 15.61$ & 60 & $371.33 \pm 15.02$ & 60 & $341.01 \pm 24.33$ & 60 & $301.36^{a} \pm 12.74$ & 60 & $272.63 \pm 12.59$ \\
\hline $\mathbf{S}_{3}$ & 62 & $409.47 \pm 16.03$ & 62 & $369.76 \pm 15.43$ & 62 & $340.46 \pm 24.99$ & 62 & $293.08^{\mathrm{b}} \pm 13.08$ & 62 & $253.58 \pm 12.93$ \\
\hline \multicolumn{11}{|c|}{ Lactation Order } \\
\hline $\mathbf{L}_{1}$ & 30 & $301.70^{\mathrm{c}} \pm 22.91$ & 30 & $291.39^{c} \pm 22.05$ & 30 & $252.17^{\mathrm{c}} \pm 35.71$ & 30 & $232.74^{c} \pm 18.70$ & 30 & $208.56 \pm 18.47$ \\
\hline $\mathbf{L}_{2}$ & 31 & $391.42^{\mathrm{bc}} \pm 21.98$ & 31 & $361.13^{b c} \pm 21.15$ & 31 & $323.92^{\mathrm{bc}} \pm 34.26$ & 31 & $290.27^{\mathrm{b}} \pm 17.94$ & 31 & $261.42 \pm 17.72$ \\
\hline $\mathbf{L}_{3}$ & 39 & $404.74^{b} \pm 20.09$ & 39 & $374.20^{\mathrm{b}} \pm 19.33$ & 39 & $339.57^{b} \pm 31.31$ & 39 & $278.17^{b c} \pm 16.39$ & 39 & $248.08 \pm 16.19$ \\
\hline $\mathbf{L}_{4}$ & 38 & $421.87^{\mathrm{a}} \pm 19.38$ & 38 & $380.97^{\mathrm{ab}} \pm 18.65$ & 38 & $356.04^{\mathrm{ab}} \pm 30.20$ & 38 & $310.67^{\mathrm{ab}} \pm 15.81$ & 38 & $266.54 \pm 15.62$ \\
\hline $\mathbf{L}_{5}$ & 31 & $418.49^{\mathrm{ab}} \pm 21.57$ & 31 & $404.61^{\mathrm{a}} \pm 20.76$ & 31 & $423.18^{a} \pm 33.62$ & 31 & $316.83^{\mathrm{a}} \pm 17.60$ & 31 & $273.66 \pm 17.39$ \\
\hline
\end{tabular}

Table.2 Least square means of MMY 6 TO MMY 10 in HF×Girhalfbreds

\begin{tabular}{|c|c|c|c|c|c|c|c|c|c|c|}
\hline Effect & $\mathbf{N}$ & MMY6 & $\mathbf{N}$ & MMY7 & $\mathbf{N}$ & MMY8 & $\mathbf{N}$ & MMY9 & $\mathbf{N}$ & MMY10 \\
\hline$\mu$ & 167 & $219.39 \pm 7.80$ & 160 & $191.12 \pm 7.35$ & 151 & $172.04 \pm 6.53$ & 140 & $144.93 \pm 8.14$ & 115 & $130.71 \pm 8.87$ \\
\hline \multicolumn{11}{|c|}{ Period of Calving } \\
\hline $\mathbf{P}_{1}$ & 72 & $268.33^{\mathrm{a}} \pm 11.04$ & 72 & $224.97^{\mathrm{a}} \pm 10.02$ & 69 & $209.92^{\mathrm{a}} \pm 8.74$ & 68 & $151.92 \pm 10.59$ & 56 & $121.58 \pm 11.58$ \\
\hline $\mathbf{P}_{2}$ & 65 & $214.18^{\mathrm{b}} \pm 11.66$ & 61 & $187.53^{b} \pm 10.86$ & 58 & $153.99^{b} \pm 9.47$ & 49 & $141.18 \pm 12.33$ & 40 & $138.82 \pm 13.62$ \\
\hline $\mathbf{P}_{3}$ & 30 & $175.66^{c} \pm 17.22$ & 27 & $160.87^{c} \pm 16.49$ & 24 & $152.22^{\mathrm{bc}} \pm 14.90$ & 23 & $141.69 \pm 18.46$ & 19 & $131.74 \pm 19.95$ \\
\hline \multicolumn{11}{|c|}{ Season of Calving } \\
\hline $\mathbf{S}_{1}$ & 45 & $215.84 \pm 14.15$ & 43 & $201.91 \pm 13.29$ & 42 & $176.65 \pm 11.45$ & 39 & $146.68 \pm 14.30$ & 32 & $134.60 \pm 15.64$ \\
\hline$S_{2}$ & 60 & $228.54 \pm 12.05$ & 58 & $194.93 \pm 11.08$ & 57 & $173.15 \pm 9.56$ & 53 & $143.37 \pm 11.85$ & 45 & $121.76 \pm 12.88$ \\
\hline$S_{3}$ & 62 & $213.78 \pm 12.37$ & 59 & $176.53 \pm 11.59$ & 52 & $166.33 \pm 10.64$ & 48 & $144.75 \pm 13.43$ & 38 & $135.78 \pm 14.75$ \\
\hline \multicolumn{11}{|c|}{ Lactation Order } \\
\hline $\mathbf{L}_{1}$ & 30 & $185.63 \pm 17.69$ & 29 & $172.10^{\mathrm{d}} \pm 16.49$ & 29 & $153.64 \pm 14.11$ & 29 & $129.92 \pm 17.02$ & 24 & $133.14 \pm 18.68$ \\
\hline $\mathbf{L}_{2}$ & 31 & $225.89 \pm 16.96$ & 30 & $200.09^{\mathrm{a}} \pm 15.61$ & 28 & $191.76 \pm 13.78$ & 25 & $146.39 \pm 17.65$ & 21 & $108.53 \pm 19.16$ \\
\hline $\mathbf{L}_{3}$ & 38 & $212.05 \pm 15.72$ & 35 & $193.34^{\mathrm{cd}} \pm 14.84$ & 32 & $170.92 \pm 13.31$ & 29 & $163.16 \pm 16.73$ & 25 & $160.76 \pm 17.83$ \\
\hline $\mathbf{L}_{4}$ & 37 & $227.70 \pm 15.15$ & 35 & $195.53^{\mathrm{ab}} \pm 14.23$ & 33 & $174.69 \pm 12.49$ & 30 & $151.65 \pm 15.66$ & 25 & $140.61 \pm 16.97$ \\
\hline $\mathbf{L}_{5}$ & 31 & $245.67 \pm 16.64$ & 31 & $194.55^{\mathrm{b}} \pm 15.09$ & 29 & $169.19 \pm 13.38$ & 27 & $133.54 \pm 16.60$ & 20 & $110.53 \pm 19.17$ \\
\hline
\end{tabular}


The influence of period of calving on monthly milk yield of fourth month was significant $(\mathrm{P}<0.01)$. Similar results were reported in, HF $\times$ Girhalfbreds (Deokar et al., 2017), Phule Triveni cows (Kamble 2014), Kale et al., (2001a) in Triple cross bred, Raut et al., (2017) in HF $\times$ Girhalfbreds. In $\mathrm{HF} \times$ Girhalfbreds, monthly milk yield of fourth month $(\mathrm{kg})$ of cows calved during different period viz., $\mathrm{P} 1(342.98 \pm 11.68), \mathrm{P} 2(272.30 \pm$ 12.13) and $\mathrm{P} 3(241.92 \pm 18.21)$ was significantly different from each other. The results revealed that the monthly milk yield of fourth month linearly decreased in cows calved during succeeding periods over preceding i.e. $\mathrm{P} 1$ to $\mathrm{P} 3$ in $\mathrm{HF} \times$ Gir cows.

The variation due to season of calving in fourth monthly milk yield was non-significant in $\mathrm{HF} \times$ Girhalfbreds. This result was in accordance with Deokar et al., (2017) in HF $\times$ Girhalfbreds, Kamble (2014) in Phule Triveni cows, Pandey et al., (2018) and Pandey and Raja (2019) in Sahiwal cattle, Raut et al., (2017) in HF $\times$ Girhalfbreds. However contradictory results were obtained by Kale $e t$ al., (2001a) in Triple cross bred. In presents study, the highest MMY4 was observed in cows calved during season winter (301.36 \pm $12.74 \mathrm{~kg})$ followed by summer $(293.08 \pm$ $13.08 \mathrm{~kg})$ and lowest in rainy $(262.76 \pm 14.66$ $\mathrm{kg})$.

The difference due to order of lactation in fourth monthly milk yield $(\mathrm{kg})$ was significant $(\mathrm{P}<0.01)$ in $\mathrm{HF} \times$ Girhalfbreds.

Similar results were obtained by Kale et al., (2001a) in Triple cross bred. In HF $\times$ Girhalfbreds, the highest MMY4 was observed in cows during L5 (316.83 \pm 17.60$)$ followed by L4 (310.67 \pm 15.81$)$, L2 (290.27 \pm 17.94), L3 (278.17 \pm 16.39$)$ and lowest in L1(232.74 \pm 18.70$)$ lactation. In HF $\times$ Gir cows in the present study no specific trend in various lactations was noticed for MMY4.The difference in MMY4 among total cows calved during L5 and L4, L2 andL3 and L4 and L3 and L1 were at par to each other.

\section{Fifth monthly milk yield 5 (MMY5)}

The overall least squares mean of monthly milk yield of fifth month in HF $x$ Girhalfbreds was $251.65 \pm 8.11 \mathrm{~kg}$.

The influence of period of calving on monthly milk yield of fifth month was significant $(\mathrm{P}<0.01)$.Similar results were reported in HF×Girhalfbreds (Deokar et al., 2017), Phule Triveni cows (Kamble 2014), Kale et al., (2001a) in Triple cross bred, Raut et al., (2017) in HFxGirhalfbreds. In HF $\times$ Girhalfbreds, monthly milk yield of fifth month $(\mathrm{kg})$ of cows calved during period $\mathrm{P} 1(302.76 \pm 11.54) \mathrm{P} 2(244.45 \pm 11.98)$ and P3(207.75 \pm 17.99$)$ was significantly different from each other.

The difference in monthly milk yield fifth among total cows calved during P1 was significantly higher than P3.The results revealed that the monthly milk yield of fifth month linearly decreased in cows calved during succeeding periods over preceding i.e. P1 to P3 in HF $\times$ Gir cows.

The variation due to season of calving in monthly milk yield of fifth was nonsignificant in $\mathrm{HF} \times$ Girhalfbreds. This result was in accordance with Deokar et al., (2017) in HF $\times$ Girhalfbreds, Kamble (2014) in Phule Triveni cows, Pandey et al., (2018) and Pandey M. and Raja K.N. (2019) in Sahiwal cattle, Raut et al., (2017) in HF $\times$ Girhalfbreds. However contradictory results were obtained by Kale et al., (2001a) in Triple cross bred. In presents study, the highest MMY5 was observed in cows calved during season winter $(272.63 \pm 12.59 \mathrm{~kg})$ followed by summer $(253.58 \pm 12.93 \mathrm{~kg})$ and lowest in rainy $(228.75 \pm 14.49 \mathrm{~kg})$. 
The difference due to order of lactation in monthly milk yield of fifth $(\mathrm{kg})$ was nonsignificant in $\mathrm{HF} \times$ Girhalfbreds. In $\mathrm{HF} \times$ Girhalfbreds, the highest MMY5 (kg) was observed in cows during L5 (273.66 \pm 17.39) followed by L4 (266.54 \pm 15.62), L2 (261.42 $\pm 17.72), \mathrm{L} 3(248.08 \pm 16.19)$ and lowest in L1 (208.56 \pm 18.47) lactation. In HF $\times$ Gir cows in the present study no specific trend in various lactations was noticed for MMY5.

\section{Sixth monthly milk yield (MMY6)}

The overall least squares mean of Monthly milk yield of sixth month in $\mathrm{HF} \times$ Girhalfbreds was $219.39 \pm 7.80 \mathrm{~kg}$.

The influence of period of calving on monthly milk yield of sixth month was significant $(\mathrm{P}<0.01)$ in $\mathrm{HF} \times$ Gircrossbreds. Similar results were reported in $\mathrm{HF} \times$ Girhalfbreds (Deokar et al., 2017), Phule Triveni cows (Kamble, 2014), Kale et al., (2001a) in Triple cross bred, Raut et al., (2017) in HF $\times$ Girhalfbreds. In $\mathrm{HF} \times$ Girhalfbreds, monthly milk yield of sixth month $(\mathrm{kg})$ of cows calved during $\mathrm{P} 1(268.33 \pm 11.04)$ was significantly higher than those in P2(214.18 \pm 11.66) and P3(175.66 \pm 17.22$)$ which were significantly different from each other. The results revealed that the monthly milk yield of sixth month linearly decreased in cows calved during succeeding periods over preceding i.e. $\mathrm{P} 1$ to $\mathrm{P} 3$ in $\mathrm{HF} \times$ Gircows.

The variation due to season of calving in in monthly milk yield of sixth was nonsignificant in $\mathrm{HF} \times$ Girhalfbreds. This result was in accordance with Deokar et al., (2017) in HF $\times$ Girhalfbreds, Kamble (2014) in Phule Triveni cows, Pandey et al., (2018) and Pandey and Raja (2019) in Sahiwal cattle, Raut et al., (2017) in HF $\times$ Girhalfbreds (238.19). However contradictory results were obtained by Kale et al., (2001a) in Triple cross bred. In presents study, the highest
MMY6 was observed in cows calved during season winter $(228.54 \pm 12.05 \mathrm{~kg})$ followed by rainy $(215.84 \pm 14.15 \mathrm{~kg})$ and lowest in summer $(213.78 \pm 12.37 \mathrm{~kg})$.

The difference due to order of lactation in monthly milk yield of sixth $(\mathrm{kg})$ was nonsignificant in HF $\times$ Girhalfbreds. Contradictory results were obtained by Kale et al., (2001a) in Triple cross bred. In HF $\times$ Girhalfbreds, the highest MMY6 was observed in cows during L5 $(245.67 \pm 16.64)$ followed by L4 (227.70 \pm 15.15$)$, L2(225.89 $\pm 16.96)$, L3 $(212.05 \pm 15.72)$ and lowest in L1(185.63 \pm 17.69$)$ lactation. In HF X Gir cows in the present study no specific trend in different lactations was noticed for MMY6.

\section{Seventh monthly milk yield (MMY7)}

The overall least squares mean of monthly milk yield of seventh month in HF $x$ Girhalfbreds was $191.12 \pm 7.35 \mathrm{~kg}$.

The influence of period of calving on monthly milk yield of seventh month was significant $(\mathrm{P}<0.01)$ in $\mathrm{HF} \times$ Girhalfbreds. Similar results were reported in $\mathrm{HF} \times$ Girhalfbreds (Deokaret al., 2017) and Phule Triveni cows (Kamble 2014), Kale et al., (2001a) in Triple cross bred. In HF $\times$ Girhalfbreds, monthly milk yield of seventh month $(\mathrm{kg})$ of cows calved during P1(224.97 \pm 10.02$)$ was significantly higher than those in $\mathrm{P} 2(187.53 \pm 10.86)$ and $\mathrm{P} 3(160.87 \pm 16.49)$ which were significantly differed from each other. The results revealed that the monthly milk yield of seventh month linearly decreased in cows calved during succeeding periods over preceding i.e. P1 to $\mathrm{P} 3$ in $\mathrm{HF} \times$ Gir cows.

The variation due to season of calving in monthly milk yield of seventh was nonsignificant in $\mathrm{HF} \times$ Girhalfbreds. This result was in accordance with Deokar et al., (2017) in HF $\times$ Girhalfbreds, Kamble (2014) in Phule 
Triveni cows, Pandey et al., (2018) and Pandey and Raja (2019) in Sahiwal cattle. However contradictory results were obtained by Kale et al., (2001a) in Triple cross bred. In presents study, the highest MMY7 was observed in cows calved during season rainy $(201.91 \pm 13.29 \mathrm{~kg})$ followed by winter $(194.93 \pm 11.08 \mathrm{~kg})$ and lowest in summer $(176.53 \pm 11.59 \mathrm{~kg})$.

The difference due to order of lactation in monthly milk yield of seventh (kg) was nonsignificant in HF $\times$ Girhalfbreds. Contradictory results were obtained by Kale et al., (2001a) in Triple cross bred (265.13 44.38). In HF $\times$ Girhalfbreds, the highest MMY7 was observed in cows during L2 $(200.09 \pm 15.61)$ followed by L4 (195.53 \pm 14.23), L5 (194.55 \pm 15.09), L3 (193.34 \pm 14.84) and lowest in L1 (172.10 \pm 16.49) lactation. In $\mathrm{HF} \times \mathrm{Gir}$ cows in the present study no specific trend in various lactations was noticed for MMY7.

\section{Eighth monthly milk yield (MMY8)}

The overall least squares mean of monthly milk yield of eighth month in $\mathrm{HF} \times$ Girhalfbreds was $172.04 \pm 6.53 \mathrm{~kg}$.

The influence of period of calving on monthly milk yield of eighth month was significant $(\mathrm{P}<0.01)$.Similar results were reported in HF $\times$ Girhalfbreds (Deokar et al., 2017), Phule Triveni cows (Kamble 2014), Kale et al., (2001a) in Triple cross bred. In HF $\times$ Girhalfbreds, monthly milk yield of eighth month $(\mathrm{kg})$ of cows calved during P1(209.92 $\pm 8.74)$ was significantly higher than those in $\mathrm{P} 2(153.99 \pm 9.47)$ and $\mathrm{P} 3(152.22 \pm 14.90)$ which were at par to each other.

The difference in MMY8 among total cows calved during P2 and P3 were at par to each other. The results revealed that the monthly milk yield of eighth month linearly decreased in cows calved during succeeding periods over preceding i.e. $\mathrm{P} 1$ to $\mathrm{P} 3$ in $\mathrm{HF} \times$ Gir cows.

The variation due to season of calving in monthly milk yield of eighth month was nonsignificant in $\mathrm{HF} \times$ Girhalfbreds. This result was in accordance with Deokar et al., (2017) in HF X Girhalfbreds, Kamble (2014) in Phule Triveni cows, Pandey M. et al., (2018) and Pandey M. and Raja K.N. (2019) in Sahiwal cattle. However contradictory results were obtained by Kale et al., (2001a) in Triple cross bred. In present study, the highest MMY8 was observed in cows calved during season rainy $(176.65 \pm 11.45 \mathrm{~kg})$ followed by winter $(173.15 \pm 9.56 \mathrm{~kg})$ and lowest in summer $(166.33 \pm 10.64 \mathrm{~kg})$.

The difference due to order of lactation in monthly milk yield of eighth month $(\mathrm{kg})$ was non-significant in $\mathrm{HF} \times$ Girhalfbreds. Contradictory results were obtained by Kale et al., (2001a) in Triple cross bred. In HF $\times$ Girhalfbreds, the highest MMY8 was observed in cows during L2 $(191.76 \pm 13.78)$ followed by L4 (174.69 \pm 12.49$)$, L3 (170.92 $\pm 13.31)$, L5 $(169.19 \pm 13.38)$ and lowest in L1(153.64 \pm 14.11) lactation. In HF $\times$ Gir cows in the present study no specific trend in various lactations was noticed for MMY8.

\section{Ninth monthly milk yield (MMY9)}

The overall least squares mean of monthly milk yield of ninth month in HF $\times$ Girhalfbreds was $144.93 \pm 8.14 \mathrm{~kg}$.

The influence of period of calving on monthly milk yield of ninth month was nonsignificant $(\mathrm{P}<0.01)$. Contradictory results were obtained by Kale et al., (2001a) in Triple cross bred. In $\mathrm{HF} \times$ Girhalfbreds, monthly milk yield of ninth month $(\mathrm{kg})$ of cows calved during P1(151.92 \pm 10.59$)$ was higher than those in P3(141.69 \pm 18.46$)$ and $\mathrm{P} 2(141.18 \pm 12.33)$. The results revealed that 
the monthly milk yield of ninth month has no specific trend of period of calving.

The variation due to season of calving in monthly milk yield of ninth month was nonsignificant in $\mathrm{HF} \times$ Girhalfbreds. This result was in accordance with Deokar et al., (2017) in HF $\times$ Girhalfbreds, Kamble (2014) in Phule Triveni cows, Pandey M. et al., (2018) and Pandey M. and Raja K.N. (2019) in Sahiwal cattle, Kale et al., (2001a) in Triple cross bred. In presents study, the highest MMY9 was observed in cows calved during season rainy $(146.68 \pm 14.30 \mathrm{~kg})$ followed by summer $(144.75 \pm 13.43 \mathrm{~kg})$ and lowest in winter $(143.37 \pm 11.85 \mathrm{~kg})$.

The difference due to order of lactation in monthly milk yield ninth (kg) was nonsignificant in $\mathrm{HF} \times$ Girhalfbreds. Contradictory results were obtained by Kale et al., (2001a) in Triple cross bred. In HF $\times$ Girhalfbreds, the highest MMY9 was observed in cows during L3 (163.16 \pm 16.73) followed by L4 (151.65 \pm 15.66$)$, L2 (146.39 $\pm 17.65)$, L5 (133.54 \pm 16.60$)$ and lowest in L1(129.92 \pm 17.02$)$ lactation.

\section{Tenth monthly milk yield 10(MMY10)}

The overall least squares mean of Monthly milk yield of tenth month in $\mathrm{HF} \times$ Girhalfbreds was $130.71 \pm 8.87 \mathrm{~kg}$.

The influence of period of calving on monthly milk yield of tenth month was nonsignificant. Contradictory results were obtained by Kale et al., (2001a) in Triple cross bred. In $\mathrm{HF} \times$ Girhalfbreds, monthly milk yield of tenth month $(\mathrm{kg})$ of cows calved during P2(138.82 \pm 13.62$)$ was numerically higher than those in P1(121.58 \pm 11.58$)$ and $\mathrm{P} 3(131.74 \pm 19.95)$. The results revealed that the monthly milk yield of tenth month had no specific trend in various period of calving.
The variation due to season of calving in monthly milk yield of tenth month was nonsignificant in $\mathrm{HF} \times$ Girhalfbreds. This result was in accordance with Deokar et al., (2017) in HF $\times$ Girhalfbreds, Kamble (2014) in Phule Triveni cows, Pandey et al., (2018) and Pandey and Raja (2019) in Sahiwal cattle, Kale et al., (2001a) in Triple cross bred. In presents study, the highest MMY10 was observed in cows calved during season summer $(135.78 \pm 14.75 \mathrm{~kg})$ followed by rainy $(134.60 \pm 15.64 \mathrm{~kg})$ and lowest in winter $(121.76 \pm 12.88 \mathrm{~kg})$.

The difference due to order of lactation in monthly milk yield of tenth month $(\mathrm{kg})$ was non-significant in $\mathrm{HF} \times$ Girhalfbreds. Contradictory results were obtained by Kale et al., (2001a) in Triple cross bred. In HF $\times$ Girhalfbreds, the highest MMY10 was observed in cows during L3 $(160.76 \pm 17.83)$ followed by L4 (140.61 \pm 16.97), L1 (133.14 $\pm 18.68)$, L5 $(110.53 \pm 19.17)$ and lowest in L2 $(108.53 \pm 19.16)$ lactation. In $\mathrm{HF} \times$ Gir cows in the present study no specific trend in various lactations was noticed for MMY10.

\section{References}

Behera R., Mandal A., Rai S., Karunakaran M. and Mondal M. (2020). Temperature Humidity Index and it's relationship with production traits of dairy cattle and buffaloes - Review. International Journal of Livestock Research 10(3):38-48.

Deokar, D. K., Raut D. R., Bhoite U. Y., Gaikwad U. S. and Mandakmale S. D. (2017). Prediction of 305 days milk yield from part lactation records in $\mathrm{Hf}$ $\mathrm{x}$ Girhalfbred cows. Contemporary Research in India 7(2):193-196.

Harvey W.R. (1990).Least-squares analysis of data with unequal subclass numbers.ARS H-4, U.S.D.A, Washington. 
Kamble S.M. (2014). Prediction of 305 days milk yield from part lactation records in Phule Triveni cows.M.sc.(agri.) thesis submitted to M.P.K.V. rahuri.

Kale, D.D., Ulmek B.R., Deokar, D.K. and Pachpute, S.T. (2001). Genetic studies on peak milk yield in Triple crossbred cows.

J.Maharashtra Agric.Univ.26(2):216-218.

Kramer, C.V. (1957). Extension of multiple range test to group correlated adjusted mean. Biometrics, 13: 13-20.

Pandey M. and Raja K.N., Saleem Yousuf and Gupta A.K. (2018). Effect of nongenetic factors on first lactation 305 days and lifetime milk yield in Sahiwal cattle. Indian J Dairy Sci 72(1): 89-92. Pandey M. And Raja K.N. (2019). Analysis of non-genetic factors influencing monthly test day milk yield records in Sahiwal cattle. Bulletin of Environment, Pharmacology and Life Sciences Bull. Env. Pharmacol. Life Sci., 8(9):98-101.

Raut, D.R., Deokar, D.K., Bhoite, U.Y., Gaikwad, U.S., and Mandakmale, S.D., (2017). Prediction of 305 days milk yield from part lactation recors in $\mathrm{HF}$ Girhalfbred cows. Contemporary Research in India.7(2):193-196.

\section{How to cite this article:}

Ghoshita Suryakant Hingonekar, Dilip Kundalik Deokar, Swapnali Uttamrao Rokade and Harshavardhan Shahaji Sonawane. 2021. Effect of Non-genetic Factors on Monthly Milk Yield HF $\times$ GIR Halfbreds. Int.J.Curr.Microbiol.App.Sci. 10(01): 155-164.

doi: https://doi.org/10.20546/ijcmas.2021.1001.018 